\title{
PELATIHAN BRAIN GYM (SENAM OTAK) PADA PESERTA PPG ASRAMA RUSUNAWA 1 UNIVERSITAS NEGERI JAKARTA
}

\author{
Dr. Taufik Rihatno \\ Fakultas Ilmu Olahraga, Universitas Negeri Jakarta \\ E-mail: taufikrihatno@yahoo.co.id
}

\begin{abstract}
ABSTRAK
Aerobic aerobics training activities for students of SM 3T who live arranged by the State University of Jakarta is an activity of provision of skills in order to prepare them later ready to go public in general and especially as teachers who will live in the outermost, leading, and left (3T), because the teacher is still considered part of the community is a skilled and omniscient person especially in the 3T area. This implementation was conducted on July 22 and 23, 2017 with the number of participants who were in this training as many as 31 students in various kinds of the study program, such as; Prodi Physical Education, Health and Recreation, Bahasa Indonesia, English, Education of Cultural Arts and Economic Education. The location of the training in Rusunawa 1 Campus B State University J1 Pemuda No 10 Rawamanguna Jakarta is quite a lot of participants who want to participate with various factors of reason of their participation, among others; 1) The Brain Gym is already known, but the Brain Gym movements developed by the Deputy of Sports Empowerment of the State Ministry of Youth and Sports are not familiar with the participants, 2) Want to know, learn and master the motion skills of Brain Gym so they can be an instructor, 3) To maintain health. To undertake this activity, the Faculty of Sport of the State University of Jakarta through the Institute of Community Service held a Brain Gym Training at the participants of Rusunawa 1 PPG SM-3T State University of Jakarta to be more confident and optimize the ability of the psychomotor aspect with the competence it has. In terms of implementation, participants look enthusiastic, passionate and motivated to follow the course of this event until the deadline has been determined. Responses and responses from participants either verbally or practice movements can be passed well. So in the end this activity can be concluded that the participants get useful knowledge. In the end, it is expected that similar activities can be carried out periodically to the wider community with a broader target.
\end{abstract}

Keywords: aerobic gymnastics, rusunawa, brain gym

\section{ABSTRAK}

Kegiatan pelatihan senam aerobik bagi mahasiswa SM 3 T yang tinggal dirusunawa 1 Univeristas Negeri Jakarta merupakan kegiatan pemberian bekal keterampilan dalam rangka mempersiapkan mereka nantinya siap terjun kemasyarakat secara umumnya dan khususnya sebagai guru yang akan tinggal di daerah-daerah terluar, terdepan, dan tertinggal (3T), sebab guru masih dianggap sebagian masyarakat adalah orang yang terampil dan serba tahu apalagi di daerah $3 T$ tersebut. Pelaksanaan ini dilakukan pada tanggal 22 dan 23 Juli 2017 dengan jumlah peserta yang itu dalam pelatihan ini sebanyak 31 orang mahasiswa dengan berbagai macam prodi, seperti; prodi Pendidikan Jasmani, Kesehatan dan Rekreasi, Bahasa Indonesia, Bahasa Inggris, Pendidikan Seni Budaya dan Pendidikan Ekonomi. Tempat pelaksanaan pelatihan di Rusunawa 1 Kampus B Universitas Negeri Jl Pemuda No 10 Rawamanguna Jakarta cukup banyak peserta yang mau ikut dengan berbagai faktor alasan keikutsertaan mereka, antara lain; 1) Brain Gym ini sudah di kenal, tetapi gerakan-gerakan Brain Gym yang dikembangakan Deputi Pemberdayaan Olahraga Kementrian Negara Pemuda dan Olahraga peserta belum mengenalnya, 2) Ingin mengetahui, mempelajari dan menguasai keterampilan gerak dari Brain Gym sehingga mereka bisa menjadi instruktur, 3) Untuk menjaga kesehatan. Untuk merelisasikan pelaksanaan kegiatan ini, maka Fakultas Ilmu Olahraga Universitas Negeri Jakarta melalui Lembaga Pengabdian Kepada Masyarakat mengadakan Pelatihan Brain Gym Pada Peserta Asrama Rusunawa 1 PPG SM-3T Universitas Negeri Jakata agar meraka lebih percaya diri dan mengoptimalkan kemampuan dari aspek psikomotor dengan kompetensi yang dimilikinya. Dari segi pelaksanaannya, peserta terlihat antusias, semangat dan termotivasi mengikuti jalannya acara ini sampai pada batas waktu yang telah ditentukan. Tanggapan dan respon dari peserta baik secara lisan maupun praktek gerak dapat dilalui dengan baik. Sehingga pada akhirnya kegiatan ini dapat disimpulkan bahwa peserta mendapatkan ilmu yang bermanfaat. Pada akhirnya diharapkan kegiatan serupa dapat dilaksanakan secara periodik pada masyarakat luas dengan sasaran yang lebih luas lagi.

Kata kunci: senam aerobic, rusunawa, brain gym 


\section{PENDAHULUAN}

\section{A. Latar Belakang Masalah}

Pendidikan dengan kelengkapan asrama atau pendidikan berasrama bukan sesuatu yang baru dalam konteks pendidikan di Indonesia. Telah lama lembaga-lembaga pendidikan di Indonesia menerapkan konsep pendidikan modern berasrama dalam wujud "Pondok Pesantren", tidak terkecuali pondok pesantren modern sebagai perkembangan dari pondok pesantren tradional tetap konsisten menjadikan asrama sebagai bagian yang tidak terpisahkan dari sistem pendidikan pesantren.

Perkembangan akhir-akhir ini cukup banyak bermunculan sekolah yang melengkapi fasilitas dengan asrama, dikenal dengan sekolah berasrama (boarding school) yang didasari dengan pertimbangan, bahwa untuk mencapai tujuan pendidikan yang lebih utuh, yang mencakup cipta, rasa, karsa dan karya sehingga menghasilkan lulusan yang tidak hanya unggul dalam berpikir tetapi juga berkepribadian mulia. Dengan pendidikan berasrama dapat menerapkan program pendidikan yang komprehensif holistic mencakup keagamaan, pengembangan akademik, life skill, wawasan NKRI dan membangun wawasan global. Oleh karena itu, pendidikan asrama digunakan sebagai salah satu pertim bangan untuk menyelenggarakan program Pendidikan Profesi Guru (PPG).

Universitas Negeri Jakarta (UNJ) merupakan salah satu perguruan tinggi yang memilki program pengadaan tenaga kependidikan yang memenuhi persyaratan, maka Universitas Negeri Jakarta menyelenggarakan program PPG tersebut. Untuk kurun waktu sekarang ini, Universitas Negeri Jakarta menyelenggarakan program PPG $T$ dan PPG SM-3T yang berasrama, dimana pesertanya tersebut bertempat tinggal di Rusunawa pada lingkungan Fakultas Ilmu Keolahragaan. Dengan keberadaan peserta PPG T dan PPG SM-3T yang berpenghuni dari program studi PGSD, Pendidikan Jasmani, Seni Budaya, MIPA dan Bahasa di Rusunawa tersebut, ada program kegiatankegiatan yang dikembangkan di asrama tersebut, seperti; kegiatan keagamaan, seni, olahraga, kepemimpinan dan sebagainya. Oleh karena, calon-calon guru ini dipersiapkan menjadi guru yang handal, siap diterjunkan di daerah-daerah terluar, terdepan, dan tertinggal (3T). Oleh karena itu, caloncalon guru tersebutharus banyak diberikan bekal ilmu pengetahuan dan keterampilan. Dengan dibekali keterampilan senam otak yang diharapkan nantinya dapat membantu didalam membangun kepercayaan masyarakat sebab guru masih dianggap sebagian masyarakat adalah orang yang terampil dan serba tahu apalagi di daerah 3T tersebut.

\section{B. Perumusan Masalah}

Berdasarkan uraian latar belakang maka permasalahan yang akan dibahas dalam Pelatihan Brain Gym (Senam Otak) Pada Peserta PPG SM-3T Asrama Rusunawa 1 Universitas Negeri Jakarta, yaitu bagaimana kompetensi seorang instruktur dalam mengembangkan variasi gerak, gerakan dengan irama?

\section{Tujuan Kegiatan}

Kegiatan ini bertujuan untuk melaksanakan Tri Darma Perguruan Tinggi, yaitu perwujudan dan pengabdian masyarakat dengan cara memberikan bekal dan pemahaman kepada para masyarakat yang bekerja tentang pentingnya olahraga dan memberikan informasi tentang kesehatan sesuai dengan kebutuhan masyarakat. Tujuan khusus dalam pelatihan ini adalah: mahasiswa SM 3T Rusunawa 1 dapat memahami dan memilki tentang kompetensi pengetahuan dan keterampilan dalam gerakan Brain Gym sehingga nantinya dapat menyebarluaskan gerakan Brain Gym tersebut di sekolahsekolah atau dilingkungan masyarakat.

\section{Manfaat Kegiatan}

Dari kegiatan ini diharapkan dapat memberikan manfaat yang besar tentang;

1. Untuk meningkatkan mahasiswa dalam keprofesionalannya kelak menjadi seorang guru.

2. Mahasiswa dapat mengenal tentang gerakan Brain Gym yang dikembangankan dari penggerak senam KEMENPORA

Jurnal Sarwahita Vol. 14 No. 02 Tahun 2017 | 124 
3. Diharapkan nantinya dapat membantu dan meningkatkan dalam proses pembelajaran siswa.

\section{TINJAUAN PUSTAKA}

\section{A. Brain Gym}

Senam Otak atau lebih dikenal dengan sebutan Brain Gym merupakan serangkaian gerakan sederhana yang dilakukan untuk merangsang kerja otak dan fungsi otak secara maksimal. Kantor Kemenpora melalui Deputi Pemberdayaan Olahraga mengembangan gerakan Brain Gym memadukan dengan kesegaran jasmani sehingga munculah penyebutan Senam Kesegaran Jasmani yang merupakan perpaduan antara kesegaran fisik melalui senam kesegaran jasmani dan pengelolaan keseimbangan otak melalui Brain Gym yang dikemas secara dinamis dan tepat sasaran untuk membantu peserta didik terutama tingkat sekolah dasar. Pendapat lain Brain Gym adalah serangkaian gerak sederhana yang menyenangkan dan digunakan oleh para siswa di Educational Kinesiology (Edu-K) untuk meningkatkan kemampuan belajar mereka dengan menggunakan keseluruhan otak. Gerakan-gerakan ini membuat segala macam pelajaran menjadi lebih mudah, dan terutama Sangat bermanfaat bagi kemampuan akademik. Kata Education berasal dari kata Latin educare yang berarti "menarik keluar". Kinesiology dikutip dari bahasa Yunani kinesis, berarti "gerakan" dan merupakan pelajaran gerakan tubuh manusia. Edu-K adalah satu sistem yang memberdayakan semua orang yang belajar, tanpa batas umur, dengan menggunakan aktivitas gerakan-gerakan untuk menarik keluar seluruh potensi seseorang.

Biasanya pendidik mengatasi kegagalan dengan membuat program untuk lebih memotivasi, menekankan, mengulang-ulang, dan "memaksa" belajar. Program ini berhasil sampai tingkat tertentu. Tetapi mengapa beberapa belajar bisa melakukan dengan baik sementara yang lainnya tidak? Di Edu-K kita melihat bahwa beberapa orang mencoba terlalu keras dan mematikan ("switch off") mekanisme integrasi otak dan yang diperlukan untuk menyerap pelajaran secara keseluruhan. Informasi diterima oleh otak bagian belakang sebagai pesan (impress), tetapi tidak dapat diungkapkan oleh otak bagian depan (express). Ketidakmampuan untuk menerangkan apa yang sudah dipelajari menyebabkan belajar terperangkap dalam sindrom kegagalan.

Jalan keluarnya adalah belajar dengan seluruh kemampuan otak dan melalui pembaruan pola bergerak serta kegaitan Brain Gym sehingga belajar menguasai bagianbagian otak yang sebelumnya terhambat. Perubahan belajar dan perilaku kadangkadang amat cepat dan mendalam, karena para pelajar menemukan cara untuk menerima informasi dan pada saat yang sama dapat mengungkapkan diri. Buku-buku lain dalam seri ini termasuk EduK for Kids, mengajarkan prosedur pembaruan pola bergerak yang direkomendasikan untuk semua orang yang ingin meningkatkan kualitas hidup, kemampuan belajar, dan menikmati gerakannya. Buku Brain Gym mengajarkan gerakan yang mudah, yang telah mengubah kehidupan banyak orang sejak awal diperkenalkan. Gerakan Brain Gym dapat membantu banyak orang, muda atau tua, untuk mengoptimalkan kemampuannya.

Kegiatan Brain Gym ini dibuat guna menstimulasi (Dimensi Lareralitas), meringankan (Dimensi Pemfokusan), atau merelaksasi (Dimensi Pemusatan) siswa yang terlibat dalam situasi belajar tertentu. Gerakan-gerakan khusus telah diamati agar lebih bermanfaat untuk mengatasi hambatan belajar perorangan berikut pola-pola individunya. Di dalam buku Brain Gym menuntun pendidik atau orang tua mengamati dan mengenali pola-polanya sehingga membuat pengalaman belajar lebih bermutu dan tepat. Otak manusia, seperti hologram, terdiri dari tiga dimensi dengan bagian-bagian yang saling berhubungan sebagai satu kesatuan. Itu sebabnya, bayi atau balita secara global dapat menangkap dunia orang dewasa dan menciptakannya menjadi dunia baru lagi. Pelajaran lebih mudah diterima bila mengaktifkan sejumlah panca indera dari pada 
hanya diberikan secara abstrak saja. Akan tetapi, otak manusia juga spesifik tugasnya, untuk aplikasi gerakan Brain Gym dipakai istilah 1) Dimensi Lateralitas untuk belahan otak kiri dan kanan. Dimensi Lateralitas, dengan cara mengintegrasi kedua sisi tubuh (bilateral integration) untuk bekerja pada "bidang tengah". Ketercapaian gerakan ini menstimulasi koordinasi kedua belahan otak yang merupakan kemampuan dasar akademik, misalnya: mampu memproses kode linear, simbol tulisan, mendengar dan melihat. Lateralitas (sisi) tubuh manusia dibagi dalam sisi kiri dan sisi kanan. Sifat ini memungkinkan dominasi salah satu sisi misalnya menulis dengan tangan kanan atau kiri, dan juga untuk integrasi kedua sisi tubuh (bilateral integration), yaitu untuk menyeberangi garis tengah tubuh untuk bekerja di "bidang tengah". Bila keterampilan ini sudah dikuasai, orang akan mampu memproses kode linear, simbol tertulis (mis. Tulisan), dengan dua belahan otak dari kedua jurusan: kiri ke kanan atau kanan ke kiri, yang merupakan kemampuan dasar kesuksesan akademik. Ketidakmampuan untuk menyeberangi garis tengah mengakibatkan apa yang disebut "ketidakmampuan belajar" (learning disabled) atau "disleksia". 2) Dimensi Pemfokusan untuk bagian belakang otak (batang otak atau brainstem) dan bagian depan otak (frontal lobes). Dimensi Fokus, dengan cara menyeberangi "Garis Tengah Partisipasi" yang menghubungkan otak bagian belakang (occipital) dan depan (Front lobe). Ketidakseimbangan pada dimensi ini dapat mengakibatkan ketidakmampuan dalam mengekspresikan diri sendiri dan kurang aktif dalam proses belajar. 3) Dimensi Pemusatan untuk sistem limbis (midbrain) dan otak besar (cerebral cortex). Dimensi Pemusatan, dengan cara mengaitkan fungsi otak bagian atas dan bawah atau disebut juga bagian tengah sistem limbis (midbarain) yang berhubungan dengan informasi emosional serta otak besar (cerebrum) untuk berfikir abstrak.

Dengan adanya kerjasama antara ketiga dimensi di atas diharapkan terjadi keseimbangan seluruh sistem sehingga memudahkan dalam berkomunikasi, pemahaman dan pengaturan gerakan.

\section{B. Gerakan Brain Gym}

Senam Kesegaran Otak merupakan gerakan dinamis perpaduan antara prinsipprinsip dasar Brain Gym dan kesegaran jasmani. Pola yang digunakan lebih mengacu pada penciptaan gerakan yang meliputi: pengeluaran energi, konsentrasi, dinamika gerak yang mengandung unsur fun, peregangam otot dan keseimbangan.

Sebagian dari gerakan Senam Kesegaran Otak terdapat hubungan ataupun peralihan yang membutuhkan suatu konsentrasi. Hal ini melatih pada keseimbangan ketrampilan bergerak antara berusaha keras (putaran lambat/ low gear) sampai mudah (putaran cepat/ high gear). Ketika mampu dalam mengakses pada high gear ke low gear ataupun sebaliknya, dapat melakukan: gerakan secara otomatis ke gerakan terencana; gerakan dari seluruh ke sebagian dan sebaliknya; berpikir dan gerak bersama-sama ke gerak dihentikan untuk berpikir; ingatan ke rangsangan atau sebaliknya; otot kontaksi dan aktif ke otot relaks dan siap bergerak serta sebaliknya.

Pada pola tradisional dalam mendidik anak lebih menekankan pada gerakan lateralitas yaitu bergerak secara alami dan kanan ke kiri, sehingga target yang dicapai adalah pengembangan otak kanan dan kiri. Dengan adanya latihan gerakan Barin Gym ini diharapkan mampu membantu keseimbangan otak dalam bekerja dan dengan kerjasama antara ketiga dimensi di atas terjadi keseimbangan seluruh sistem sehingga memudahkan dalam berkomunikasi, pemahaman dan pengaturan. Sedangkan pada gerakan kesegaran jasmani dengan ritmeritme sedang low impact high intensity yang disesuaikan dengan kapasitas peserta didik, tanpa meninggalkan unsur-unsur; pemanasan, inti, dan pendinginan. Adapun gerakan Brain Gym terdiri dari; 1) Pemanasan, terdiri dari 29 gerakan, 2) Inti, terdiri dari 49 gerakan, dan 3) Pendinginan, terdiri dari 23 gerakan. Untuk melihatnya lebih jelas dapat nonton video 
yang diikutserta dalam laporan ini. (VCD terlampirkan)

\section{Latihan}

Untuk dapat mengetahui secara jelas hakikat dari latihan, sebagaimana dikatakan oleh Tudor O. Bompa latihan merupakan aktifitas olahraga yang sistematik dalam waktu yang lama, ditingkatkan secara progresif dan individual yang mengarah kepada ciri-ciri fisiologis manusia untuk mencapai sasaran yang telah ditentukan. Sedangkan latihan menurut Harsono; dapat diartikan sebagai latihan adalah proses yang sistematis dari pada berlatih atau bekerja secara berulang-ulang, dengan kian hari kian menambah jumlah beban latihan atau pekerjaan.

Latihan yang baik adalah latihan yang mentaati prinsip-prinsip latihan yang berlaku, serta memperhatikan beberapa faktor yang menjadi pegangan, sehingga tidak menyimpang dari tujuan yang ingin dicapai dan terhindar dari usaha yang sia-sia. Faktorfaktor latihan yang perlu diperhatikan tersebut antara lain:

\section{Frekuensi}

Secara umum dikatakan bahwa frekuensi merupakan suatu kepadatan kegiatan yang dilakukan, dengan demikian frekuensi latihan adalah kepadatan latihan yang terjadi atau dilakukan.

Menurut Sadoso dikatakan bahwa latihan paling sedikit tiga kali per minggu, baik untuk olahraga kesehatan maupun olahraga prestasi. Hal ini disebabkan ketahanan seseorang akan menurun setelah 48 jam tidak melakukan latihan, jadi kita usahakan sebelum ketahanan menurun harus sudah berlatih lagi.

\section{Intensitas}

Intensitas dimaksudkan adalah pembebanan yang harus diberikan dalam latihan, dimana hal tersebut tergantung pada kemampuan masing-masing orang. Dimana untuk mengetahui tinggi rendahnya intensitas biasanya dengan cara memeriksa denyut nadi pada saat latihan. Rentangan denyut nadi olahraga kesehatan ialah antara denyut nadi istirahat sampai $85 \%$ denyut nadi maksimal sesuai usia. Sedangkan menurut Marta Dinata, dikatakan bahwa denyut nadi maksimal adalah $=(220$-umur $)$, sedangkan Denyut nadi latihan (Zone Training) $=(220$-umur x $72 \%$ $87 \%$ DM. Sedangkan 60\%-70\% dari denyut nadi maksimum adalah Zone pembakaran lemak. Secara umum diartikan bahwa 60-70\% dari denyut jantung maksimum kita adalah zone pembakaran lemak, dimana $85 \%$ dari total kalori yang terbakar adalah lemak.

3. Tempo

Tempo latihan adalah berapa waktu yang dibutuhkan dalam suatu proses latihan, atau dapat dikatakan sebagai lamanya latihan yang dilakukan. Dalam suatu pembahasan bebas dikatakan bahwa latihan yang baik dan efektif adalah latihan yang memenuhi 3 komponen utama, yaitu pemanasan, latihan inti serta diakhiri dengan pendinginan, dan ketiga komponen tersebut dilakukan paling tidak selama 1 jam, dimana latihan inti mempunyai porsi paling besar.

4. Type (Jenis dan Urutan)

Didalam suatu latihan umumnya terdapat 2 pilihan latihan yaitu latihan aerobik atau dengan menggunakan lebih banyak oksigen, dan umumnya memakan waktu yang cukup lama, serta latihan anaerobik. Umumnya hal ini disesuaikan dengan kebutuhan fisik, termasuk latihan penguatan jantung dan paruparu, atau yang sering muncul dimana seseorang ingin mengurangi prosentase lemak tubuhnya, maka latihan yang bersifat aerobik dapat menjadi pilihan, sehingga proses pembakaran lemak akan lebih maksimall dilakukan.

Olahraga merupakan investasi hidup yang sangat penting bagi keberlangsungan kehidupan manusia, karena melalui olahraga akan dihasilkan tingkat kesehatan dan kebugaran tubuh yang selalu diingini oleh semua orang pada umumnya. Banyak cara manusia agar tubuhnya tetap sehat dan bugar seperti pengaturan pola makan, melakukan aktivitas gerak tertentu dan lain sebagainya, yang kesemuanya dilakukan hanya untuk memperoleh kebahagian bathin dan tidak mengalami ketidakseimbangan dalam tubuh. Sehingga dalam hal ini, Soekarman menyimpulkan bahwa kesehatan adalah suatu 
E-ISSN: 2597-8926

kondisi yang meliputi kesehatan badan, rohani (mental) dan sosial dan bukan hanya keadaan yang bebas dari penyakit, cacat dan kelemahan.

Dengan demikian sehat bukan hanya pada fisik dan mental saja, namun juga pada lingkungan tempat dimana kita tinggal. Oleh karenanya pemerintah pernah memberlakukan program memasyarakatkan olahraga dan mengolahragakan masyarakat karena sangat meyakini bahwa lingkungan dan teman atau kerabat sangat mendukung tingginya partisiapasi masyarakat untuk berolahraga dengan tujuan melalui kesegaran jasmani dan rohani tercipta produktivitas kerja yang tinggi.

\section{Sistimatika Latihan}

Latihan Brain Gym tidak terlepas dari sistematika umum berolahraga yang terdiri dari tiga fase, yaitu :

\section{Pemanasan (Warming Up)}

Dalam fase ini dapat menggunakan pola warming up yang didahului oleh kegiatan stretching / penguluran otot -otot tubuh dan dilanjutkan dengan gerakan dinamis pemanasan. Pola yang kedua yaitu kebalikan dari pola pertama dimana seseorang melakukan pemanasan dinamis dulu kemudian dilanjutkan dengan melakukan kegiatan penguluran otot - otot tubuh / stretching.

Kegiatan pemanasan / warming up ini memiliki tujuan yaitu: meningkatkan elastisitas otot dan ligamen di sekitar persendian untuk mengurangi resiko cedera. Meningkatkan suhu tubuh dan denyut nadi sehingga mempersiapkan diri agar siap menuju ke aktivitas utama, yaitu aktivitas latihan.

Dalam fase ini, pemilihan gerakan harus dilakukan dan dilaksanakan secara sistematis, runtut dan konsisten. Misalnya, apabila gerakan tersebut dimulai dari kepala, maka urutannya adalah kepala, lengan, dada, pinggang dan kaki. Begitu pila sebaliknya.

2. Kegiatan Inti

Fase latihan adalah fase utama dari sistematika latihan Brain Gym. Dalam fase ini target latihan harus tercapai. Salah satu indikator latihan telah memenuhi target adalah dengan mempredikdi bahwa latihan tersebut telah mencapai training zone. Training zone adalah daerah ideal denyut nadi dalam fase latihan. Rentang training zone adalah $60 \%$ $90 \%$ dari denyut nadi maksimal seseorang (DNM). Denyut nadi yang dimiliki oleh setiap orang berbeda, tergantung dari tingkat usia seseorang. Berikut ini adalah rumus untuk mencari denyut nadi maksimal seseorang (DNM):

$$
\text { DNM = } 220 \text { - Usia (Tahun) }
$$

Umumnya rumus ini digunakan untuk atlet. Sedangkan rumus menghitung denyut nadi maksimal bagi orang awam / bukan atlet adalah

$$
\text { DNM = } 200-\text { Usia (Tahun) }
$$

\section{Pendinginan (Cooling Down)}

Pada fase ini hendaknya melakukan dan memilih gerakan - gerakan yang mampu menurunkan frekuensi denyut nadi untuk mendekati denyut nadi yang normal, setidaknya mendekati awal dari latihan. Pemilihan gerakan pendinginan ini harus merupakan gerakan penurunan dari intensitas tinggi ke gerakan intensitas rendah. Ditinjau dari segi faal, perubahan dan penurunan intensitas secara bertahap tersebut berguna untuk menghindari penumpukan asam laktat yang akan menyebabkan kelelahan dan rasa pegal pada bagian tubuh/otot tertentu.

\section{MATERI DAN METODE}

\section{A. Kerangka Pemecahan Masalah}

Upaya meningkatkan pengetahuan dan keterampilan pada peserta PPG asrama Rusunawa 1 Universitas Negeri Jakarta guna membentuk guru profesional sesuai dengan kurikulum yang dikembangkan di asrama yang bersifat komplementer dimana pada kehidupan asrama lebih mengembangkan; kemampuan berkomunikasi, sikap moral, Jurnal Sarwahita Vol. 14 No. 02 Tahun 2017 | 128 
tanggungjawab, sikap sosial kerja sama, kepemimpinan dan sejumlah keterampilan yang mendukung profesi. Kegiatan senam di Rusunawa dilaksanakan satu bulan tiga kali. Dengan adanya kegiatan rutin tersebut dengan tuntutan guru dimasyarakat yang tinggi dimana guru adalah orang yang serba tahu maka peserta PPG Rusunawa 1 UNJ selalu diberi bekal berbagai keterampilanketerampilan sehingga mereka siap berada dilingkungan masyarakat.

Selain itu, di sekolah-sekolah saat ini mulai mengembangkan kegiatan olahraga bersama melalui kegiatan senam bersama satu minggu sekali yang biasanya diselenggarakan pada hari jum'at. Dengan pembekalan pelatihan Brain Gym akan penambahan kepercayaan diri dan keterampilan seorang guru khususnya peserta PPG yang nantinya dipersiapkan guru-guru yang handal.

Dalam upaya kearah tersebut, maka Dosen Universitas Negeri Jakarta khususnya Dosen Fakultas Ilmu Olahraga melalui kegiatan Pengabdian Kepada Masyarakat perlu membantu mahasiswa peserta PPG Universitas Negeri Jakarta untuk menguasai pengetahuan dan memiliki keterampilan tentang Brain Gym nantinya dapat mengaplikasikannya dilapangan dengan harapan dapat memberikan nuansa yang lain dalam performence seorang guru baik dilingkungan sekolah, dimasyarakat secara umum dan secara khususnya membantu perbaikan dalam proses pembelajaran.

\section{B. Realisasi Pemecahan Masalah}

Setelah dikaji dan diketahui apa yang menjadi kebutuhan peserta PPG Rusunawa 1 UNJ dimana mereka dipersiapkan untuk menjadi guru yang handal diantaranya meningkatkan kemampuan siswa di dalam proses pembelajaran. Oleh sebab itu, salah salah satunya untuk membantu mengembangan diri guna meningkatkan kualitas dalam proses pembelajaran dapat dilakukan dengan pelatihan Brain Gym. Oleh karena tujuan dari pola gerakan-gerakan Brain Gym diharapkan; 1) Membantu keseimbangan otak antara otak kiri dan otak kanan pada peserta siswa, 2) Mengoptimalkan bagian - bagian otak, 3) Membantu keseimbangan dalam putaran lambat ke putaran cepat ataupu sebaliknya, 4) Memberikan kebugaran fisik yang optimal pada siswa, 5) Memasyarakatkan bergerak pada siswa. Dengan mengoptimalkan fungsi otak diharapkan nantinya dapat membantu di dalam proses pembelajaran yang lebih baik. Dengan demikian pelatihan Brain Gym sangat perlu untuk diberikan kepada peserta PPG Rusunawa 1 UNJ, baik itu pengetahuan dan keterampilan dari Brain Gym guna untuk menopang keprofesionalannya menjadi guru yang handal.

\section{Khalayak Sasaran}

Khalayak sasaran yang terlibat dalam kegiatan ini adalah mereka yang tinggal di asrama Rusunawa 1 Universitas Negeri Jakarta yang terdiri dari program studi PGSD, Pendidikan Jasmani, Seni Budaya, MIPA, Ekonomi dan Bahasa dimana mereka belum memiliki pengetahuan dan keterampilan tentang gerakan Brain Gym.

Peserta pelatihan Brain Gym yang nantinya diharapkan mereka mengetahui makna hidup sehat dan mampu mengembangkan Brain Gym di sekolah sekolah maupun dilingkungan masyarakat.

\section{Metode Kegiatan}

Metode yang digunakan dalam pelatihan ini adalah 1) Metode kepustakaan yaitu memberikan pemahaman kepada peserta pelatihan tentang pengetahuan, prinsip latihan, dan teknik-teknik pola gerakan yang mengacu pada literatur-literatur, referensi, artikel tentang Brain Gym, 2) Metode ceramah, metode demontrasi dan metode latihan digunakan dalam prakteknya.

\section{PEMBAHASAN DAN HASIL}

\section{A. Pembahasan}

Pelaksanaan kegiatan non akademik asrama melalui pelatihan Brain Gym di Rusunawa 1 Universitas Negeri Jakarta dapat berjalan sesuai dengan rencana program yang telah ditentukan baik dari segi waktu, tempat pelaksanaan, nara sumber dan peserta pelatihan semua telah memberikan kontribusi yang baik untuk kelancaran pelaksanan ini. 
Kegiatan pelatihan Brain Gym ini dilaksanakan di Rusunawa 1 Universitas Negeri Jakarta dengan karakteristik pesertanya adalah mahasiswa PPG SM 3T dari program studi PGSD, Pendidikan Jasmani, Seni Budaya, MIPA, Ekonomi dan Bahasa yang saat ini lagi dididik untuk menjadi guru profesional, unggul, dan bermartabat melalui kegiatan akademik dan non-akademik di asrama. Adapun peserta yang ikut dalam pelatihan Brain Gym sebanyak 31 orang peserta dan pelaksaan ini dilakukan pada tanggal 22 dan 23 Juli 2017

Selama kegiatan berlangsung semua peserta mengikuti dengan penuh semangat dengan menunjukkan rasa antusias dan keingintahuan lebih tentang isi materi baik teori maupun praktek. Hal ini disebabkan materi tersebut mereka butuhkan kemudian dari pola gerakannya ada pengembangan, yaitu perpaduan antara kesegaran fisik melalui kesegaran jasamani dan pengelolaan keseimbangan otak melalui Brain Gym, sehingga gerakan Brain Gym yang dikembangan dari Kementrian Negara Pemuda Dan OLahraga merupakan hal yang baru bagi peserta PPG Rusunawa 1 UNJ.

\section{B. Hasil Kegiatan}

Keberhasilan pelaksanaan kegiatan pelatihan Brain Gym di Rusunawa 1 Universitas Negri Jakarta ditunjukan dari jumlah peserta yang cukup banyak serta kesungguhan dan minat yang besar dari peserta, begitu juga dari tim penyaji, baik itu dari dosen FIO dan Tim aerobik Fitnes FIO yang datang tepat waktunya dan penuh semangat dalam memberikan materi.

Pihak peserta menginginkan ada program kelanjutannya karena peserta yang terlibat merasakan / memperoleh kemanfaatannya dari pelatihan ini dan mereka juga berharap dari kelanjutan pelatihan ini menjadikan mereka jadi seorang instruktur yang profesional sehingga sebagai sarana untuk mendapatkan sumber penghasilan.

\section{KESIMPULAN DAN SARAN}

\section{A. Kesimpulan}

Berdasarkan hasil pelaksanaan kegiatan Pengabdian Kepada Masyarakat di Rusunawa 1 Universitas Negeri Jakarta pada paserta PPG dapat ditarik kesimpulan, bahwa 1) Peserta pelatihan sangat antusias dalam mengikuti pelatihan Brain Gym, 2) Peserta pelatihan merasa ada peningkatan pengetahuan tentang Brain Gym, 3) Gerakan-gerakan Brain Gym yang dikembangankan Kementian Negara Pemuda dan Olahraga dapat meningkatkan kesegaran jasmani dan keseimbangan otak antara otak kanan dan otak kiri.

\section{B. Saran}

Berdasarkan pelatihan yang telah dilaksanakan pada peserta PPG SM 3T Rusunawa 1 Universitas Negeri Jakarta, ada beberapa saran yang dapat dipertimbangkan:

1. Bagi peserta pelatihan Brain Gym hendaknya mengetahui dan mampu melakukan gerakan Brain Gym sesuai dengan takaran yang pas dan ideal.

2. Hasil pelatihan ini diharapkan Peserta PPG Rusunawa 1 UNJ mampu mengaplikasikan secara sistimatis gerakan dari Brain Gym dalam kehidupannya, khususnya dilingkungan sekolah.

\section{DAFTAR PUSTAKA}

Abu Ahmadi, 1991, Sosiologi Pendidikan. Jakarta: PT. Rineka Cipta.

Deputi Pemberdayaan Olahraga Kementrian Negara Pemuda Dan Olahraga, Brain Gym Model Pengembangan Senam Kesegaran Otak. Jakarta: Kemenegpora

Gerungan, W.A. 1996. Psikologi Sosial, Bandung: PT. Eresco.

Grasha, Anthony F, Daniel S, Kirschenbaum, 1980. Psychology of Adjusment and Competence An Approach, Cambridge: Winthrop Publishers, Inc.

Harton, Paul dan Chester L, Hunt, 1992, Sosiologi, Jilid ii, Jakarta: Erlangga.

Paul E. Dennison dan Gail E. Dennision, 2003, Brain Gym. Alih Bahasa, Ruslan dan Rahayu Morris. Jakarta: PT Grasindo. 
DOI: https://doi.org/10.21009/sarwahita.142.06

P-ISSN: 0216-7484

E-ISSN: 2597-8926

Richard W. Bowers \& Edward L. Fox. 1992, Sport Physiology. Dubuque Lowa: Wm. C Browns.

Tudor O. Bompa. 1994. Theory and Methodology of Training. The Key to Athletic Performance. 